\title{
Wpływ terapii uzdrowiskowej na obniżenie natężenia odczuwania bólu u pacjentów z chorobą zwyrodnieniową stawów i kręgosłupa
}

\section{The impact of the spa therapy on reduction of the perception of pain intensity in patients with degenerative joints and disc disease}

\author{
Jadwiga Kuciel-Lewandowska, Małgorzata Paprocka-Borowicz
}

Katedra Fizjoterapii Uniwersytetu Medycznego we Wrocławiu

ul. Grunwaldzka 2, 50-355 Wrocław

Kierownik: dr hab., prof. nadzw. Matgorzata Paprocka-Borowicz

\section{SUMMARY}

Introduction: Degenerative joints and disc disease is accompanied by chronic pain which is the main symptom of the disease. Medical spa therapy has the task of providing comprehensive treatment embracing diseases of limbs as well as other systems and the essential role of medical treatment, in particular spa therapy, is pain relief.

The aim of the study was to evaluate the effect of the spa treatment on the level of pain perception in patients with degenerative joints and disc disease.

Material and methods: The observation embraced 120 people with degenerative joints and disc disease treated in the spa. The study included a comprehensive therapy conducted over a 21-day stays at the spa Przerzeczyn-Zdrój with the application of selected physical treatments, physiotherapy and the use of therapeutic natural resources: peloid mud and healing radon-sulphide water. Moreover, there was psychological counseling and health education conducted. The study also included observation of 21 persons from the control group. However, the patients in the control group did not benefit from balneotherapy, psychological care and education. There was a standard VAS scale for pain and non-standard questionnaire of pain assessment constructed for the study purposes. The assessment of pain using the VAS scale and questionnaire of pain assessment both in the study group and the control group were performed before and after the treatment. The results were analyzed statistically, there was Statistica program in Polish version used. In the analysis of the obtained results there were two tests scheduled: the sign test, the Wilcoxon test and descriptive statistics.

Results: As a result of the spa therapy and treatments administered on an outpatient basis there was reduction of pain intensity observed.

Conclusions: 1 . Spa therapy and outpatient treatment reduce the level of pain in patients with degenerative joints and disc disease. 2. The reduction of pain level was more effective in case of therapy conducted in the spa.

Key words: pain, spa, degenerative joints disease, degenerative disc disease.

\section{STRESZCZENIE}

Wstęp: Chorobie zwyrodnieniowej stawów i kręgosłupa towarzyszy przewlekły ból, będący głównym objawem chorobowym. Zadaniem medycyny uzdrowiskowej jest kompleksowa terapia w zakresie schorzeń narządu ruchu i innych układów oraz walka z bólem

Celem pracy była ocena wpływu terapii uzdrowiskowej na poziom odczuwania bólu u pacjentów z chorobą zwyrodnieniową stawów i kręgosłupa.

Materiał i metody: Obserwacją objęto 120 osób z chorobą zwyrodnieniową stawów i kręgosłupa leczonych w uzdrowisku. W badaniu uwzględniono kompleksową terapię prowadzoną w czasie 21-dniowych turnusów w uzdrowisku Przerzeczyn-Zdrój z zastosowaniem wybranych zabiegów fizykalnych, kinezyterapii oraz naturalnych surowców leczniczych: borowiny i wody leczniczej radonowo-siarczkowej. Ponadto prowadzono poradnictwo psychologiczne oraz edukację zdrowotną. W badaniu uwzględniono również obserwację 21-osobowej grupy kontrolnej. Pacjenci z grupy kontrolnej nie korzystali z balneoterapii oraz opieki psychologicznej i edukacji. Zastosowano standardową wizualno-analogową skalę oceny bólu (VAS) oraz niestandardową ankietę oceny bólu skonstruowaną na potrzeby badania. Ocenę bólu za pomocą VAS, a także ankiety oceny bólu w grupie badanej i grupie kontrolnej wykonywano przed terapią oraz po jej zakończeniu. Otrzymane wyniki opracowano statystycznie za pomocą programu Statistica PL. W ocenie uzyskanych wyników zastosowano test znaków i test Wilcoxona oraz statystyki opisowe.

Wyniki: W wyniku terapii uzdrowiskowej oraz terapii prowadzonej ambulatoryjnie uzyskano poprawę w zakresie obniżenia natężenia bólu.

Wnioski: 1. Leczenie uzdrowiskowe oraz leczenie prowadzone ambulatoryjnie wpływają na obniżenie poziomu bólu u pacjentów z chorobą zwyrodnieniową stawów i kręgosłupa. 2. Większą skuteczność w zakresie obniżenia poziomu bólu stwierdzono w przypadku terapii prowadzonej w uzdrowisku.

Słowa kluczowe: ból, uzdrowisko, choroba zwyrodnieniowa stawów, choroba zwyrodnieniowa kręgosłupa. 


\section{WSTĘP}

Chorobie zwyrodnieniowej stawów i kręgosłupa towarzyszy przewlekły ból będący głównym objawem chorobowym. Ból ogranicza sprawność i aktywność ruchową, opóźnia zdecydowanie powrót do zdrowia, życia społecznego oraz pracy zawodowej, niosąc za sobą poważne koszty ekonomiczne. Zadaniem medycyny uzdrowiskowej jest kompleksowa terapia w zakresie schorzeń narządu ruchu i innych układów oraz walka z bólem. W terapii uzdrowiskowej wykorzystywane są zabiegi z zakresu fizykoterapii, kinezyterapii, balneoterapii i psychoterapii. Ponadto prowadzona jest edukacja zdrowotna dotycząca diety, aktywności ruchowej i szeroko pojętej profilaktyki.

Ból - według Międzynarodowego Towarzystwa Badania Bólu - jest „przykrym zmysłowym i emocjonalnym odczuciem związanym z aktualnym lub potencjalnym uszkodzeniem tkanek lub opisywanym jako takie uszkodzenie" [1, 2]. Ból należy do najczęściej odczuwanych dolegliwości. Uznaje się go za doznanie fizyczne, neurologiczne i psychologiczne. Zjawisko to jest rodzajem nieprzyjemnego odczucia, które w pewnym zakresie pełni funkcje obronne, dlatego też w toku ewolucji ból nie podlegał procesom przystosowawczym. Stanowi sygnał alarmowy, informujący o zagrożeniu życia lub uszkodzeniu struktur organizmu. Jako sygnał alarmowy aktywuje organizm do podjęcia działania w celu poprawy stanu zdrowia lub ratowania życia [3]. Od strony klinicznej ból opisywany jest przez kilka cech: natężenie, czas trwania, lokalizację, charakter oraz reakcję na niego.

Ból należy do zjawisk o złożonym charakterze. Ogromną rolę w odczuwaniu bólu odgrywa reakcja psychiczna, decydująca o poziomie cierpienia. W zależności od ogólnego stanu zdrowia i sytuacji życiowej reakcja psychiczna może przebiegać w różny sposób. Obok zjawisk psychologicznych o powstaniu bólu decyduje subiektywne odczucie chorego związane z naruszeniem ciągłości tkanek lub zagrożeniem takim uszkodzeniem. Ponadto odczuwanie bólu związane jest z szeregiem zjawisk odruchowych zależnych od poszczególnych pięter układu nerwowego [4, 5].

Postawa wobec choroby to kolejny ważny czynnik, który wpływa na odczucia bólowe. Wyróżnia się dwie postawy: obojętną oraz pełną napięcia i wyczekiwania. U osób charakteryzujących się pierwszą postawą stwierdzono większą tolerancję na ból, natomiast napięcie i wyczekiwanie na bodziec bólowy zwiększa intensywność jego doznawania oraz czyni go bardziej przykrym dla chorego [6].

Celem pracy była ocena wpływu terapii uzdrowiskowej na poziom odczuwania bólu u pacjentów z chorobą zwyrodnieniową stawów i kręgosłupa.

\section{MATERIA $~ I$ METODY}

Grupę badanych tworzyło 120 pacjentów (79 kobiet i 41 mężczyzn) z chorobą zwyrodnieniową stawów i kręgosłupa lub dyskopatią. Wiek chorych wahał się w zakresie 31-78 lat. Średnia wieku badanych pacjentów wynosiła 54,8 lat. Grupę kontrolną stanowili pacjenci Poradni Rehabilitacyjnej Wrocławskiego Centrum Zdrowia SP ZOZ Przychodni „Stabłowice”. Osoby te pozostawały w leczeniu ambulatoryjnym z powodu choroby zwyrodnieniowej stawów i kręgosłupa. W grupie kontrolnej znalazło się 21 osób (6 mężczyzn i 15 kobiet) w wieku 37-79 lat (średnia wieku 55,5 lat). Badanie wykonano przed terapią i po jej zakończeniu wśród pacjentów z grupy badanej oraz grupy kontrolnej. Kryterium doboru była obecność choroby zwyrodnieniowej stawów i/lub kręgosłupa oraz brak przeciwwskazań do leczenia. Pacjenci grupy badanej i kontrolnej korzystali z serii zabiegów w zależności od zgłaszanych dolegliwości. W obu grupach zalecono serię 10 zabiegów z poszczególnych typów terapii w zależności od potrzeb i rodzaju schorzenia. Dawki z zakresu fizykoterapii w obu grupach dobierano tak samo. Przykładowy zestaw zabiegów zastosowany w uzdrowisku to kąpiele radonowo-siarczkowe, okłady borowinowe, gimnastyka lecznicza grupowa i indywidualna, biostymulacja promieniowaniem laserowym oraz prądy interferencyjne.

W kompleksowej terapii uzdrowiskowej u pacjentów obserwowanej grupy zalecono:

- kąpiele radonowo-siarczkowe całościowe lub częściowe, obejmujące kończyny górne i/lub dolne (temp. $37-38^{\circ} \mathrm{C}$, czas trwania zabiegu $20 \mathrm{~min}$ ),

- okłady borowinowe częściowe (temp. $40-42^{\circ} \mathrm{C}$, czas trwania zabiegu $20 \mathrm{~min}$ ),

- gimnastykę leczniczą w basenie z wodą obojętną leczniczo (czas trwania zabiegu $30 \mathrm{~min}$ ),

- gimnastykę indywidualną na przyrządach i gimnastykę grupową, które dobierano odpowiednio dla każdego pacjenta, uwzględniając jego indywidualną sprawność (średni czas trwania zabiegu wynosił 30-45 min),

- terenoterapię (spacer, zajęcia ruchowe w terenie),

- masaż suchy (w zależności od potrzeb dotyczył odcinka szyjnego, piersiowego lub lędźwiowego kręgosłupa),

- laseroterapię (parametry zabiegu: omiatanie, praca ciągła, długość fali 808 nm, moc 12,0 J, 400 mV; czas trwania zabiegu $30 \mathrm{~s}$ ),

- pole magnetyczne niskiej częstotliwości (kształt impulsu prostokątny, indukcja 5 mT, częstotliwość 20-50 Hz; czas trwania zabiegu $20 \mathrm{~min}$ ),

- ultrasonoterapię (parametry zabiegu: głowica $800 \mathrm{kHz} /$ $6 \mathrm{~cm}^{2}$; stosowano falę impulsową ultradźwięków $2 \mathrm{~ms}$ impuls, $9 \mathrm{~ms}$ przerwa, $\mathrm{w}$ dawce $0,5-0,6 \mathrm{~W} / \mathrm{cm}^{2} \mathrm{w}$ czasie $6 \mathrm{~min}$ ),

- krioterapię (nawiew, temp. od $-80^{\circ} \mathrm{C}$ do $-110^{\circ} \mathrm{C}$; czas trwania zabiegu 2-3 min),

- elektroterapię: prądy diadynamiczne Bernarda (parametry zabiegu: DF1 CP4 LP4), prądy interferencyjne Nemeca (zakres częstotliwości 0-100 HZ), przezskórną stymulację elektryczną (TENS) - prąd impulsowy o przebiegu prostokątnym, o czasie trwania impulsu 0,2 ms, częstotliwości $40 \mathrm{~Hz}$ oraz natężeniu regulowanym od 0-100 mA,

- światłolecznictwo: lampa Sollux z filtrem niebieskim (odległość naświetlania 30-40 cm, czas trwania $15 \mathrm{~min}$ ), lampa Bioptron (odległość naświetlania $10 \mathrm{~cm}$, czas naświetlania 5-10 min). 
Ponadto pacjenci leczeni w uzdrowisku objęci byli opieką psychologa oraz edukacją zdrowotną. Szczególną rolę w procesie leczenia odegrały unikatowe na skalę europejską wody lecznicze uzdrowiska Przerzeczyn-Zdrój. Są to wody radonowo-siarczkowe o temp. $12^{\circ} \mathrm{C}$, pH 7,62. W $1 \mathrm{dm}^{3}$ wody znajduje się 1,96 mg $\mathrm{H}_{2} \mathrm{~S}, 289,6 \mathrm{mg} \mathrm{HCO}_{3}$ oraz 2,21 nCi Rn (81,8 Bq). Należą do wód o niskiej mineralizacji.

U pacjentów w grupie kontrolnej zastosowano terapię w ciągu 10 dni zabiegowych. W leczeniu zastosowano fizykoterapię, masaż suchy i kinezyterapię. W tej grupie pacjenci nie korzystali z zajęć na basenie, kąpieli leczniczych, terenoterapii, porad psychologa i edukacji zdrowotnej. Zazwyczaj prowadzili dotychczasowe życie domowe i zawodowe.

Na przeprowadzenie badań uzyskano zgodę Komisji Bioetycznej Uniwersytetu Medycznego we Wrocławiu (opinia nr KB-401/2008), pisemną zgodę prezesa Uzdrowiska Przerzeczyn Sp. z o.o., pisemną zgodę dyrektora Wrocławskiego Centrum Zdrowia SP ZOZ, a także indywidualne pisemne zgody pacjentów sporządzone zgodnie ze wzorem zalecanym przez Komisję Bioetyczną Uniwersytetu Medycznego we Wrocławiu. Dokumentacja znajduje się w posiadaniu autorów.

W badaniu wykorzystano standardową wizualno-analogową skalę oceny bólu (VAS) oraz niestandardową ankietę oceny bólu skonstruowaną na potrzeby badania. Ocenę bólu za pomocą obu skal wykonano w grupie badanej i grupie kontrolnej przed terapią i po jej zakończeniu.

Wizualno-analogowa skala oceny bólu jest graficzno-opisową skalą stosowaną w ocenie natężenia bólu, w której poziomowi intensywności bólu przyporządkowana jest skala numeryczna 0-10, gdzie o oznacza brak bólu, a 10 ból bardzo silny [7]. Intensywność jest najtrudniejszą do zbadania cechą bólu. Niemożliwa jest jej obiektywna ocena. Dla zobrazowania natężenia bólu wykorzystuje się skale porównujące ból z najsilniejszym, jaki badana osoba jest sobie w stanie wyobrazić [8]. Wizualno-analogowa skala oceny bólu jest najczęściej stosowanym narzędziem w ocenie intensywności bólu [9].

Ankieta oceny bólu jest niestandardową skalą przygotowaną na potrzeby obserwacji. Składa się z 15 pytań zawierających
6 odpowiedzi punktowanych (odpowiednio: a $-6 \mathrm{pkt}, \mathrm{b}-5 \mathrm{pkt}$, $\mathrm{c}-4$ pkt, d-3 pkt, e - 2 pkt, f - 1 pkt). Wyższe wartości stanowią odpowiedzi negatywne, świadczące o znacznych dolegliwościach bólowych ze współistniejącą niesprawnością i obniżoną jakością życia. Maksymalny wynik 90 pkt wskazuje na dużą niesprawność i ograniczenia spowodowane bólem, wynik minimalny 15 pkt świadczy o pełnej sprawności i braku występowania bólu. Ankieta ma także za zadanie ocenić wpływ bólu na samodzielność pacjenta, wykonywanie czynności dnia codziennego i aktywność fizyczną.

Otrzymane wyniki opracowano statystycznie za pomocą programu Statistica PL. W ocenie uzyskanych wyników zastosowano test znaków dla par powiązanych oraz test par Wilcoxona. Założono poziom istotności statystycznej $\mathrm{p} \leq 0,05$. W przypadku różnic istotnych statystycznie informacje szczegółowe o różnicach (wartości „przed terapią” mniejsze od wartości „po terapii”) czerpano ze statystyk opisowych, porównując w następującej kolejności: mediany (50.), średnie, percentyle 25. i 75 .

\section{WYNIKI}

Przed terapią średnia wartość punktowa w VAS w grupie badanej wyniosła 6,13 pkt, po leczeniu 3,67 pkt. Zgłaszany w grupie badanej ból można określić na średnim poziomie, a wartości uzyskane po kuracji wskazują na utrzymywanie się już tylko niewielkich dolegliwości. W grupie badanej przed terapią średnia wartość punktacji w ankiecie oceny bólu wyniosła 48,08 pkt, a po leczeniu 40,16 pkt. W teście Wilcoxona i w teście znaków dla VAS poziom istotności $\mathrm{p}=0,000$, dla ankiety oceny bólu $\mathrm{p}=0,000$. Porównanie wartości średniej, mediany i percentyli dla danych cech również potwierdziły zmiany przed terapią i po jej zakończeniu. Uzyskane wyniki przedstawiono w tabeli 1.

W grupie kontrolnej średnia punktacja w VAS przed terapią wyniosła 5,76 pkt, a po leczeniu 5,00 pkt. Punktacja ankiety oceny bólu dla grupy kontrolnej przedstawiała się

TABELA 1. Statystyki opisowe w ocenie wizualno-analogowej skali oceny bólu (VAS) i ankiety oceny bólu dla grupy badanej

\begin{tabular}{|c|c|c|c|c|c|c|c|c|}
\hline \multirow{2}{*}{ Parametry } & \multirow{2}{*}{$\mathrm{n}$} & \multirow{2}{*}{ Średnia } & \multirow{2}{*}{ SD } & \multirow{2}{*}{ Minimum } & \multirow{2}{*}{ Maksimum } & \multicolumn{3}{|c|}{ Percentyle } \\
\hline & & & & & & 25. & 50. & 75. \\
\hline VAS przed & 120 & 6,13 & 1,77 & 0,00 & 10,00 & 6,00 & 6,00 & 8,00 \\
\hline VAS po & 120 & 3,67 & 1,46 & 0,00 & 8,00 & 2,00 & 4,00 & 4,00 \\
\hline Ankieta oceny bólu po & 120 & 40,16 & 12,43 & 15,00 & 75,00 & 31,75 & 39,00 & 48,00 \\
\hline
\end{tabular}

TABELA 2. Statystyki opisowe w ocenie wizualno-analogowej skali oceny bólu (VAS) i ankiety oceny bólu dla grupy kontrolnej

\begin{tabular}{|c|c|c|c|c|c|c|c|c|}
\hline \multirow{2}{*}{ Parametry } & \multirow{2}{*}{$n$} & \multirow{2}{*}{ Średnia } & \multirow{2}{*}{ SD } & \multirow{2}{*}{ Minimum } & \multirow{2}{*}{ Maksimum } & \multicolumn{3}{|c|}{ Percentyle } \\
\hline & & & & & & 25. & 50. & 75. \\
\hline VAS po & 21 & 5,00 & 1,26 & 3,00 & 8,00 & 4,00 & 5,00 & 6,00 \\
\hline VAS przed & 21 & 5,76 & 1,67 & 3,00 & 9,00 & 5,00 & 6,00 & 7,00 \\
\hline Ankieta oceny bólu po & 21 & 42,90 & 12,31 & 21,00 & 69,00 & 34,50 & 40,00 & 53,00 \\
\hline Ankieta oceny bólu przed & 21 & 44,52 & 12,43 & 23,00 & 71,00 & 37,00 & 41,00 & 54,50 \\
\hline
\end{tabular}




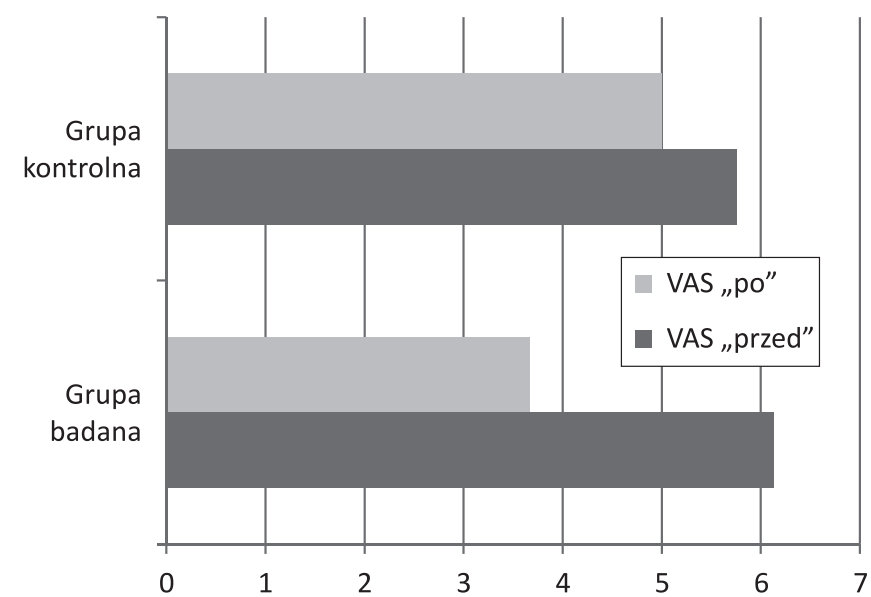

RYCINA 1. Porównanie średnich uzyskanych w wizualno-analogowej skali oceny bólu (VAS) dla obu grup

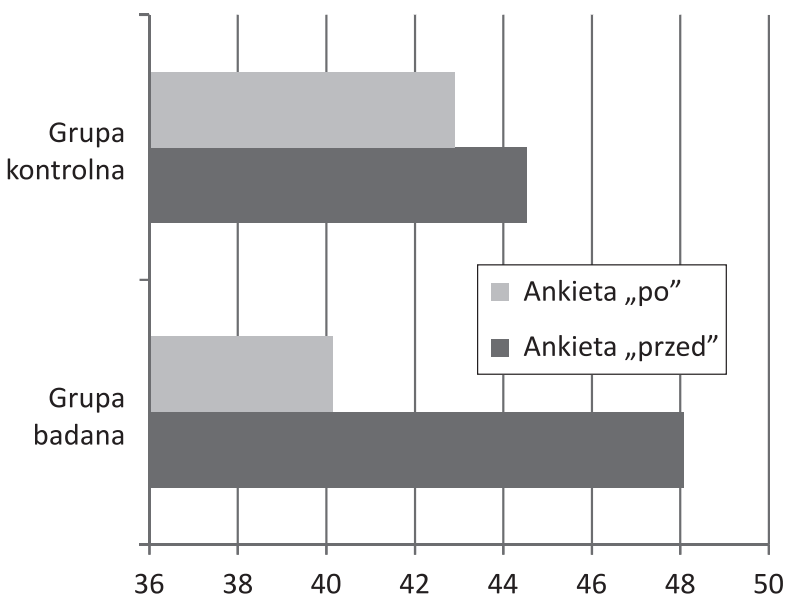

RYCINA 2. Porównanie średnich uzyskanych w ankiecie oceny bólu dla obu grup

następująco: przed leczeniem uzyskana wartość wyniosła 44,52 pkt, a po leczeniu 42,90 pkt. Dla VAS w teście Wilcoxona $\mathrm{p}=0,000$, a w teście znaków $\mathrm{p}=0,001$. Ankieta oceny bólu $\mathrm{w}$ teście Wilcoxona $\mathrm{p}=0$, w teście znaków $\mathrm{p}=0,004$. Porównanie średniej i percentyli dla danych cech również potwierdziły zmiany przed terapią i po jej zakończeniu. Uzyskane wyniki przedstawiono w tabeli 2 .

Na rycinach 1 i 2 przedstawiono różnice wartości średnich dla poszczególnych cech w obu grupach.

\section{DYSKUSJA}

Celem terapii choroby zwyrodnieniowej stawów i kręgosłupa jest zniesienie lub ograniczenie występowania dolegliwości bólowych. Bezpośrednie działanie przeciwbólowe zabiegów fizykalnych i balneologicznych wynika z oddziaływania na układ nerwowy [10]. Pośrednio zmniejszenie doznań bólowych następuje poprzez poprawę ukrwienia w miejscu objętym zabiegiem, stymulację wydzielania związków o działaniu przeciwbólowym oraz zmniejszenie nadmiernego napięcia mięśniowego i aparatu więzadłowego [11,12]. Włókna nerwowe posiadają pewien próg pobudliwości, który określa się przez siłę bodźca konieczną do ich pobudzenia. Im słabszy jest bodziec zdolny do pobudzenia tkanki nerwowej, tym niższy jest jej próg pobudliwości. Próg pobudliwości włókien nerwowych podwyższa m.in. elektroterapia, promieniowanie laserowe, jak również światło niebieskie [13, 14]. Medycyna fizykalna jako składowa terapii uzdrowiskowej wykorzystuje w procesie leczenia wiele rodzajów energii, szczególnie w zakresie walki z bólem [15].

Prąd elektryczny powoduje uwolnienie histaminy i innych substancji o działaniu rozszerzającym naczynia krwionośne [16]. Zwiększa się ukrwienie, a w konsekwencji lepsze jest odżywienie tkanek, zaopatrzenie w tlen i substancje odżywcze. Następuje zwiększony odpływ krwi żylnej i limfy z tkanek, przyspieszając usuwanie z nich związków chemicznych pobudzających receptory bólu, głównie mediatory bólu i stanu zapalnego, a także szkodliwe produkty przemiany materii, zwłaszcza beztlenowej $[17,18]$. Następuje poprawa trofiki tkanek, przyspieszają się również procesy gojenia w ich obrębie.

Promieniowanie podczerwone, zwiększając stan cieplny tkanek, powoduje obniżenie napięcia mięśni, więzadeł oraz mięśniówki naczyń, przez co również zwiększa się ukrwienie i odżywienie tkanek. Ukrwienie ulega również poprawie na skutek zastosowania biostymulacji promieniowaniem laserowym. Poprzez usprawnienie dysocjacji hemoglobiny i zwiększenie przepływu krwi tętniczej promieniowanie laserowe zwiększa zaopatrzenie tkanek w tlen [19]. W wyniku jego zastosowania dochodzi również do zahamowania uwalniania zapalnych mediatorów [20]. Promieniowanie laserowe aktywizuje procesy metaboliczne, w wyniku których dochodzi do zmniejszenia bólu i obrzęku [21, 22]. Zwiększenie wydzielania endogennych opioidów, naturalnych substancji analgetycznych, jest fizjologiczną reakcją organizmu na ból. Zabiegi z zakresu elektroterapii, laseroterapii, krioterapii i światłolecznictwa wpływają na wzrost zawartości endorfin i enkefalin w tkankach $[23,24]$.

Zmienne pole magnetyczne indukuje w tkankach prąd piezoelektryczny, który aktywuje wzrost kości i wpływa na zmianę napięcia mięśni, działa przeciwbólowo, przeciwzapalnie i przeciwobrzękowo, a także aktywuje procesy oddychania tkankowego [25, 26]. Mięśnie reagując napięciem na ból w obrębie kręgosłupa, zwiększają w efekcie te doznania. Powstaje „błędne koło” bólu. Dlatego tak istotne znaczenie dla zmniejszenia dolegliwości bólowych mają działania zmniejszające napięcie mięśniowe. Promieniowanie podczerwone, zabiegi borowinowe i kąpiele lecznicze zmniejszą napięcie mięśni poprzez zwiększenie ciepłoty w okolicy zabiegowej, krioterapia poprzez wtórne ukrwienie, a prąd elektryczny przez zmniejszenie pobudliwości tkanki mięśniowej.

O właściwościach leczniczych borowiny oraz wód radonowo-siarczkowych wspomniano już w wielu pracach. Niewątpliwe peloidoterapię wykorzystuje się w leczeniu schorzeń reumatologicznych, neurologicznych i ortopedycznych. W stanie podostrym i przewlekłym schorzeń narządu ruchu zastosowanie tych zabiegów powoduje ustąpienie lub znaczne zmniejszenie dolegliwości bólowych, poprawę zakresu ruchomości kręgosłupa i zmniejszenie napięcia mięśni przykręgosłupowych. 
W zespołach pourazowych czy stanach pooperacyjnych odnotowuje się aktywację procesów regeneracyjnych i odbudowę uszkodzonych tkanek [27, 28]. Leczenie uzdrowiskowe z powodu działań kompleksowych z udziałem zabiegów balneoterapeutycznych, różnych form kinezyterapii, zmiany sposobu odżywiania się, odizolowania od aktywności zawodowej i społecznej oraz życia rodzinnego daje możliwość odpoczynku. W kontekście powszechnie panującego stresującego stylu życia ten element terapii uzdrowiskowej wydaje się również ważny. Odpoczynek i nieobecność stresu to brak wzmożonego napięcia mięśniowego, zwłaszcza mięśni przykręgosłupowych, a co za tym idzie - ustąpienie bólu [29].

W przeprowadzonym badaniu uzyskano poprawę w zakresie zmniejszenia bólu. Zarówno wyniki uzyskane w VAS, jak i ankiety oceny bólu wskazują, że odnotowano redukcję dolegliwości bólowych. W grupie badanej uzyskano lepszy wynik niż w grupie kontrolnej. Podobny wynik uzyskali również inni autorzy [30]. Taka skuteczność w grupie kontrolnej jest możliwa, a nawet pożądana, ponieważ była to grupa uczestnicząca w leczeniu usprawniającym w ramach opieki ambulatoryjnej. Można więc uznać, że skuteczność terapii w kontekście walki z bólem w obu grupach była porównywalna, z przewagą na korzyść grupy badanej. Wydaje się, że skuteczność leczenia w przeprowadzonym badaniu wynika z wielokierunkowości terapii uzdrowiskowej, co szczególnie w sytuacji walki z bólem zalecane jest przez innych autorów [31, 32, 33].

Badania Modrak i wsp. wykazały skuteczność okładów borowinowych w leczeniu bólu, zwiększeniu zakresu ruchomości kręgosłupa i siły mięśni przykręgosłupowych oraz dobrą tolerancję [34]. Według Miki i wsp. zabiegi borowinowe zmniejszają sztywność stawów kolanowych [35]. Praca Puszczałowskiej-Lizis i Łuczyszyn również potwierdziła wpływ kompleksowego leczenia uzdrowiskowego na poprawę parametrów czynnościowych narządu ruchu w przypadku osób z chorobą zwyrodnieniową stawów biodrowych. W badaniu wykazano wzrost zakresów ruchu w stawach biodrowych oraz siły mięśniowej kończyn dolnych wraz ze zwiększeniem masy mięśni (pomiar obwodów kończyn); uzyskano poprawę w zakresie chodu po płaskim i wchodzenia po schodach [36]. W badaniach Nitera-Kowalik i wsp. wykazano, że w przypadku osób cierpiących na chorobę zwyrodnieniową kręgosłupa prowadzony w uzdrowisku program usprawniania z zastosowaniem taśm terapeutycznych umożliwił zmniejszenie dolegliwości bólowych i poprawę jakości życia u pacjentów z zespołami bólowymi kręgosłupa [37]. Nie można również zapomnieć o skuteczności zabiegów fizykalnych w poprawie oceny bólu u pacjentów z chorobą zwyrodnieniową odcinka szyjnego. Badania własne potwierdzają skuteczność walki z bólem w przypadku choroby zwyrodnieniowej górnego odcinka kręgosłupa poprzez zastosowanie fizykoterapii [38].

Ważnym elementem kompleksowej terapii w uzdrowisku jest psychoterapia, która wpływa na poprawię stanu emocjonalnego i psychicznego oraz na skuteczność leczenia somatycznego, a także umożliwia radzenie sobie w trudnych sytuacjach i poprawę relacji społecznych. Psychoterapia wykorzystuje biblioterapię, choreoterapię, muzykoterapię oraz różne formy relaksacyjne do ogólnej poprawy stanu zdrowia kuracjuszy. Pobyt w uzdrowisku to też czas przemyśleń dotyczących wyborów życiowych, próba walki z nałogami, niekiedy zmiana stylu życia w odniesieniu do diety i aktywności fizycznej. Pobyt w pięknym otoczeniu przyrody i obecność kompetentnych pracowników wpływa na poczucie bezpieczeństwa, obniżając poziom lęku będącego czynnikiem nasilającym ból [39].

\section{WNIOSKI}

1. Leczenie uzdrowiskowe oraz leczenie prowadzone ambulatoryjnie wpływają na obniżenie poziomu bólu u pacjentów z chorobą zwyrodnieniową stawów i kręgosłupa.

2. Większą skuteczność w zakresie obniżenia poziomu bólu miała terapia przeprowadzona w uzdrowisku.

\section{PIŚMIENNICTWO}

1. Frischrenschlager O., Pucher I.: Psychological management of pain. Disabil Rehabil. 2002, 24 (8), 416-422.

2. Werke T.: Stres i ból. In: Mózg a zachowanie. Eds: T. Górska, J. Zagrodzka. PWN, Warszawa 2000, 252-268.

3. Chołodecki D., Kassolik K., Zosuł G., Krawiecka-Jaworska E.: Masaż medyczny jako środek terapeutyczny w leczeniu bólów dolnego odcinka kręgosłupa. Pol Med Rodz. 2001, (3) 3, 217-220.

4. Bornhovd K., Quante M., Glauche V., Bromm B., Weiller C., Buchel C.: Painful stimuli evoke different stimules-response functions in the amygdale, prefrontal, insula and somatosensory cortex: a single-trial fMRI study. Brain. 2002, 125 (6), 1326-1336.

5. Ozimecki M., Artym J.: Wpływ stresu psychicznego na odpowiedź immunologiczną. Post Hig Med Dośw. 2004, 58, 166-175.

6. Muller A.: Sposoby wyrażania bólu. In: Ból. Diagnostyka, leczenie i prewencja. Eds: J. Meynadier, A. Muller, C. Saint-Maurice. Gebethner i S-ka, Warszawa 1998, 33-41.

7. Wordliczek J., Dobrogowski J.: Leczenie bólu. PZWL, Warszawa 2007.

8. Domżał T.M.: Kliniczne podstawy badania i oceny bólu - wprowadzenie do tematu. Pol Przegl Neurol. 2007, 3 (4), 211-215.

9. Domżał T.M.: Ból przewlekły - problemy kliniczne i terapeutyczne. Pol Przegl Neurol. 2008, 4 (1), 1-8.

10. Demczyszak I., Wrzosek Z.: Współczesne metody elektroterapii bólu ze szczególnym uwzględnieniem przezskórnej elektro-neuro-stymulacji TENS. Fizjoter. 2001, 9 (3), 48-53.

11. Sokolnicka D., Mikuła W.: Metody oceny jakości życia mające zastosowanie w medycynie. Med Rodz. 2003, 24 (3-4), 129-132.

12. Taradaj J.: Lasery w medycynie i rehabilitacji. Fizjoter. 2001, 9 (4), 4-8.

13. Czajkowska M., Białoszewski D., Przeradzka A., Czesak T., Lewandowska M., Żarek S. et al.: Zastosowanie laseroterapii wysokoenergetycznej HILT w podwyższaniu progu bólowego u chorych leczonych metodą Ilizarowa - doniesienie wstępne. Baln Pol. 2007, 49 (4), 243-246.

14. Łukowicz M., Weber-Zimmermann M., Marszałek A.: Wpływ biostymulacji laserowej na parametry przewodnictwa w nerwie pośrodkowym. Baln Pol. 2007, 49 (4), 243-247.

15. Lisiński P., Jachowska A., Samborski W.: Metody fizjoterapeutyczne w leczeniu wysunięć krążka międzykręgowego w odcinku lędźwiowym kręgosłupa. Fizjoter Pol. 2006, 6 (3), 222-227.

16. Kujawa J., Pyszora A.: Zastosowanie elektroterapii w leczeniu bólu. Pol Med Paliat. 2003, 2 (3), 167-173.

17. Diener H.C., Maier C.: Leczenie bólu. Wydawnictwo Medyczne Urban \& Partner, Wrocław 2005.

18. Kuciel-Lewandowska J., Jarosz N.: Ocena skuteczności terapii prądami TENS i Treberta u chorych z bólem dolnego odcinka kręgosłupa. Acta Baln. 2010, 52 (1), 16-23. 
19. Kujawa J., Talar J., Gworys P., Pieszyński I., Janiszewski M.: Ocena skuteczności przeciw bólowej laseroterapii u chorych z choroba zwyrodnieniową stawu kolanowego. Ortop Traum Reh. 2004, 3, 24-27.

20. Kujawa J., Pyszczek I., Talar J., Janiszewski M.: Porównawcza ocena efektu przeciwbólowego wybranych metod fizjoterapeutycznych zespole bólo wym dolnego odcinka kręgosłupa. Fizjoter Pol. 2001, 1 (3), 271-279.

21. Demidaś A., Koziarek A., Boerner E., Ratajczak B., Kochański M.: Laser biostimulation in the regeneration of the trigeminal nerve. Fizjoter Pol. 2004, 4 (2), 129-135.

22. Sieroń A., Pasek J., Mucha R.: Lasery w medycynie i rehabilitacji. Rehab Prakt. 2006, 2, 26-30.

23. Lisiński P., Tomaszewska M., Samborski M.: Select physiotherapeutic methods in treatment of a hip joint degeneration. Fizjoter Pol. 2006, 6 (1), 45-50.

24. Sieroń A., Pasek J., Mucha R.: Światło w rehabilitacji. Rehab Prakt. 2006, 3, 20-24.

25. Pasek J., Mucha R., Sieroń A.: Magnetoledoterapia w leczeniu bólu zmian zwyrodnieniowych stawów kolanowych. Acta Bio-Optica Inform Med Inż Biomed 2006, 12 (3), 93-96.

26. Sieroń A.: Pola magnetyczne w medycynie. OPM. 2005, 5, 55-57.

27. Happich M.: Leczenie chorób reumatycznych w uzdrowisku. Standardy Med. 2003, 4 (6), 1084-1091.

28. Klimiuk P., Kuklewicz E., Sierakowski S.: Skuteczność terapeutyczna plastrów borowinowych w leczeniu choroby zwyrodnieniowej stawów obwodowych kręgosłupa. Pol Merkur Lekarski. 2004, 16 (94), 344-347.

29. Domżał T.M.: Kliniczne podstawy badania i oceny bólu - wprowadzenie do tematu. Pol Przegl Neurol. 2007, 3 (4), 211-215.

30. Mleczko M., Rudzki M., Uhryński A., Obidowski J., Rydzyk A., Hankus M.: Ocena skuteczności leczenia Uzdrowiskowego grupy kobiet z bólem krzyża skierowanych na turnus sanatoryjny do Krynicy Zdroju. Baln Pol. 2007, 49 (4), 255-264.
31. Dobrogowski J.: Niefarmakologiczne metody leczenia bólu. Pol Przegl Neurol. 2007, 3, 272-278.

32. Łuszczyn P., Puszczałowska-Lizis E.: Wpływ kompleksowego programu rehabilitacji uzdrowiskowej na parametry czynnościowe kręgosłupa Piersiowo-lędźwiowego u chorych z dyskopatią lędźwiową. Fizjoterapia. 2007, 4, 47-53.

33. Trościanko-Wilk E., Kierzek A.: Wpływ 21-dniowego turnusu rehabilitacyjnego w Uzdrowisku Świeradów Zdrój na zmniejszenie dolegliwości bólowych chorych ze zmianami zwyrodnieniowymi kręgosłupa. Acta Baln. 2013, 55, 4 (134), 265-272.

34. Modrak A., Łukowicz M., Ciechanowska K.: Ocena wpływu okładów borowinowych na dolegliwości bólowe oraz ruchomość dolnego odcinka kręgosłupa. Baln Pol. 2008, 4 (50), 313-319.

35. Mika A., Mika Ł., Dąbel E.: Wpływ terapii z zastosowaniem okładów borowinowych na dolegliwości związane z chorobą zwyrodnieniową stawu kolanowego. Reh Med. 2006, 10, 49-54.

36. Puszczałowska-Lizis E., Łuczyszyn P.: Wpływ kompleksowego programu rehabilitacji uzdrowiskowej na wybrane parametry czynnościowe narządu ruchu osób z chorobą zwyrodnieniową stawów biodrowych. Baln Pol. 2008, 50, 2 (112), 140-148.

37. Nitera-Kowalik A., Bujalski W., Durda A., Mężyńska E., Smyda A., Żak M. et al.: Zastosowanie Systemu Teragumed w kompleksowej rehabilitacji pacjentów z zespołami bólowymi kręgosłupa leczonych w 21. Wojskowym Szpitalu Uzdrowiskowo-Rehabilitacyjnym w Busku-Zdrój. Kwart Ortop. 2009, 3, 268-280.

38. Kuciel-Lewandowska J., Paprocka-Borowicz M., Jagódzka B., Kierzek A., Pozowski $A$., Ratajczak B. et al.: Ocena skuteczności wybranych zabiegów fizjoterapeutycznych w leczeniu bólu w przebiegu choroby zwyrodnieniowej kręgosłupa szyjnego. Acta Bio-Optica Inform Med Inż Biomed. 2012, 3 (18), 194-199.

39. Ponikowska I., Ossowski R.: Psychoterapia w medycynie uzdrowiskowej. Baln Pol. 2008, 4 (50), 289-293. 